The authors term this the "dark side of the placebo effect" and call for restricting "detailed information" to those potential subjects who actually request it. For those medical researchers who want to implement this suggestion, MEdicolegal NEwS proposes the following consent form:

CONSENT TO HUMAN EXPERIMENTATION

I hereby consent to be a subject in Dr. __ 's research project entitled

The project is generally safe and whatever risks exist are outweighed by the benefits to me or society. I understand that if I was informed of the specific risks and dangers of this project, one or more of these adverse reactions could occur in my mind or body. Reported side effects of full disclosure include dizziness, nausea, vomiting, mental depression, and an automobile accident. In extreme cases, I might not survive the disclosures.

I freely waive my right to know any of the specific risks of this project. I understand that if at some future time I change my mind, the risks of the project will be fully explained to me as will the "dark side of the placebo effect." I further understand that my health and safety cannot be guaranteed after such disclosure, but that every attempt will be made to keep any adverse reaction suffer confidential and under no circumstances will it be reported to any self-appointed guardian of research subjects. Editor's Note: Readers should, of course, consult their own attorneys before utilizing the form.

\section{Physicians Fees and Health Costs}

In his February 1979 speech before the Association of American Medical Schools, HEW Secretary Joseph Califano proclaimed that the United States faces a severe oversupply of physicians in the next decade. According to Califano, the "chief effect of physician oversupply is dramatically rising costs," a conclusion reinforced by a similar report from the Council on Wage and Price Stability. Secretary Califano noted that the usual forces of supply and demand have been overturned in the market for physician services.

However, in a recent editorial in The Wall Street Journal, Keith Leffler, an assistant professor of economics at the University of Washington, rejected Secretary Califano's conclusion that the classic economic forces are not in control. As an example, Leffler suggests that the high cost of specialty training in terms of time explains the pattern of physician incomes and fees across the specialties better than a view that when surpluses arise, physicians simply raise fees and expand demand by prescribing "unnecessary"

\title{
News from the Society
}

\section{ASLM Moves Offices}

Ever since its founding, the American Society of Law \& Medicine has operated out of office space adjacent to the professional offices of its president, Dr. Elliot L. Sagall. However, the Society now needs to acquire larger office space, and, effective June 1,1979 , the Society offices will be located at 520 Commonwealth Avenue, Suite 211, Boston, MA 02215.

In addition to more working space for the expanding Society staff, the new location will permit the Society to house its long-awaited Library of Law,
Medicine \& Health Care. While the Library will not be fully operational until the end of 1979, it should be possible by September of 1979 for members to submit bibliographic requests, and some provisions will be made for the circulation of materials to off-site ASLM members.

The Library effort, which has yet to receive any outside funding, together with the intensified efforts being expended on the Medicolegal Reference Shelf section of MEdicolegal NEWS, combine to make the Society and its publications the most complete and up-to-date source of information on the full range of medicolegal resources, issues, and activities. surgery, diagnostic procedures, and follow-up visits. Further, Leffler cites a Federal Trade Commission report issued last year which emphasized the restriction-of-entry problems as a means for physicians to maintain high fees.

Leffler also claims that, compared to the average college graduate, physicians earned relatively less in 1976 than they did in 1970 - exactly the response to increased supply predicted by the laws of economics. Source: THE WALL STREet JouRNAL, Friday, February 2, 1979.

\section{Federal Malpractice}

\section{Screening}

\section{Requirements in \\ Works}

Attorney General Griffin B. Bell recently announced that the Department of Justice is preparing a proposal that would set minimum standards for medical malpractice screening panels for the purpose of "weeding out unfounded claims and encouraging prompt and full settlement of those that are meritorious." A six-fold increase in hospital malpractice insurance over the past five years, which presently accounts for approximately five dollars a day per patient in medical costs, was cited as a primary reason to push the 30 states lacking such screening tribunals to create them. Source: MEDICAL WORLD NEwS, January 22, 1979.

\section{Notice of Annual Meeting of the Membership}

At approximately 1:15 p.m., May 31 , 1979, at the Copley Plaza Hotel, Boston, MA (after the luncheon of the Legal Controversies in Nursing Conference then taking place), the Annual Business Meeting of the American Society of Law \& Medicine was held. The agenda included a report of the Society's activities over the past year and the election of Council Members and Officers for the 1979-80 term. The newly elected Council Members Officers are listed on page 3 of this issue of Medicolegal News. 